WIELKIE TEMATY KULTURY W LITERATURACH SKOWIAŃSKICH

Slavica Wratislaviensia CLXVIII • Wrocław 2019•AUWr No 3875

DOI: 10.19195/0137-1150.168.41

Data przesłania artykułu: 14.09 .2017

Data akceptacji artykułu: 24.02.2018

MARIJA S. PANTOVIĆ

Универзитет у Крагујевцу, Serbia

\title{
Психолошки аспекти феномена смрти у роману Беспуће Вељка Милићевића
}

Смрт, као једна од великих тема у књижевности, претпоставља комплексност и велику семнатичку отвореност за рашчитавање текстова литерарне природе. Промишљање о смрти у роману Бесnуће (1912) Вељка Милићевића нуди се кроз главну тему романа - проблем неукорењености, однос дошљака и домаћих људи, при чему туђинци постају домаћи, a домаћини се боре с неприпадношћу психолошком, материјалном, друштвеном. Социјални проблем појављује се као основ који узоркује нагло сазревање и старење кроз разочарање што нужно имплицира и прерану смрт. Бecnyћe ce, најзад, нуди као слика немогуће психо-физичке стабилности јунака, чији животни пут, усмерен ка идеалима, води најзад у нихилизам. Гавре Ђаковић, главни лик романа, испричаће повест о вишеструким смртима што на концу доводе до психолошке смрти у субјекту самом. Као сведок семантички различитих смрти, Гавре Ђаковић постаје смрт сопства кроз укидање принципа са знаком животне активности: емоционалног, сексуалног, социјалног. Стога смо проблем смрти и разматрали као психолошки феномен, јер Гавре Ђаковић појављује се као стуб који посредно и непосредно осећа смрт, најпре туђу, затим и своју. Настојали смо да покажемо како се смрт грана и прожима све аспекте живота: друштвене, породичне, патриотске, будући да појам живота у Бесnyћy постаје најзад вредносно ништаван и празан. Ексцерпирана грађа омогућила је да се да увид у феномен смрти, како кроз смрти људи тако и кроз смрти идеала, јер у природи је човека да прихвата смрт као неминовност и несрећу, но креирање новог нивоа претпоставља питање како се жив човек носи са смртима блиских људи и најзад са смрћу сексуалности, емоције, психофизичког спокоја? Управо се у том домену Бесnyће нуди као комплексно, јер 
психологија Гавре Ђаковића даје увид у конкретне смрти, али и у оно што се не да видети, а што се разоткрива кроз Гаврин поглед и говор. Вербална недореченост условљена одсуством дијалога надомештена је дескрипцијом, просторно-пејзажним описима који кроз сопствено мртвило демаскирају људско. Тиме Гаврина перцепција туђих смрти налази упориште у психолошкој смрти сопства.

Уколико пођемо од претпоставке Новице Милића који истиче: „Пуштајући да места отпора, чиниоци разлике играју своје улоге у тексту, деконструкција настоји да им обезбеди легитимност, тј. да ревалоризује оно што је у традиционалним и стандардним процедурама херменеутичких и језичких редукција бивало потиснуто, одбачено на маргину, чак негирано", уочавамо да је управо деконструкцијом омогућен неопходан расцеп у тексту који рађа психолошке аспекте фигуре смрти, јер смрти се нижу као неминовна чињеница, но оно чему Беспуће отвара пут јесу психолошке димензије које творе сам текст романа. На почетку Милићевићевог Беспућа стоји: „Обична и свакидања гунгула у кафани; људи који се мимоилазе и поздрављају; врата која се отварају и затварају треском; момци што журно пролазе [...] у вику наручивања и празно ударање кугла на билијару [...]"2 што наизглед препоставља учмалу слику кафанске вреве творену од генерацијски различитих људи. Но, ипак, не само то. У мери у којој се да рашчитати, свака Милићевићева слика декодирање је или, пак, другостепено кодирање стварности. Стога, почетак романа јесте и сажета слика друштва у којему живи Гавре Ђаковић, а које је друштво испразне ужурбаности и празног одзвањања билијарске лопте. Уколико се појам игра односи на тип разоноде творене по одређеним правилима уз подразумеване учеснике, поставља се питање какве су природе играчи празне игре? Неминовоно празни, или чак не постоје, јер ако је игра испражњена до учмалости онда и учесници игре јесу механички покретачи билијарских кугли, а уочавамо их посредством Гавриног опажања: „И он с чуђењем посматраше мноштво ђачких лица, с картама, таковима у рукама, заваљених и без мисли [...]”3. Празна слика Гавриног погледа последица је масе коју чине фигуре људских силуета чији је ум, такође, празан.

Управо је почетном сликом омогућено разматрање и семантичко гранање аспеката живота и смрти у Бесnyћy. Деконструкција омогућава да се деструкције ликова романа припоје аутодеструкцији главног лика, Гавре Ђаковића, као стецишту смрти људи, идеала, Бога, и најзад, сопства. Говорити о субјекту који проговара с психолошког аспекта доживљаја смрти, немогућно је изван позиционирања у друштвено-породични контекст, јер како истиче Јовановић: „Уочавање утицаја културе, друштва

1 Н. Милић, АБЦ Деконструкиије, Београд 1998, с. 13.

2 В. Милићевић, Бесnуће, Београд 1982, с. 7.

3 Ibidem, c. 9-10. 
и језика постаје битна ставка у савременим тумачењима субјекта"4. У раду смо, стога, пратили, процес кретања субјекта од предтекстуалне учмалости до пута (раз)октивања који води до вишеструких смрти, другости и сопства. Условни преображај је нужан, услован је стога што је почетак преображаја почетак дискурса, предтесктуални простор постоји само као однос на претходно стање према којему се субјекат мења. О томе говори и Јовановић позивајући се на Фукоа који: „даје свом језику променљиви рад слободе и допушта могућност појединцу да разгрне наметљиве и често заробљавајуће игре дискурса и промени свој идентитет"5. Промена Гавре Ђаковића јесте кретање ка прошлости, селу и дому, дакле, реч је о психолошком, временском и простроном померању: „И он осјети жељу да види оне високе, крупне, поцрњеле људе, да им стисне њихову тврду, жуљевиту руку, да угледа ситне кућице, са црном и срулом шимлом, малим прозорчићима [...] отвореним вратима, кроз која се црвени дрхтава ватра на огњишту"6. Међутим, повратак је истовремено сећање на смрти породице које имплицирају рађање нове смрти у биолошки живом човеку. Фукоова промена идентитета у Милићевићевом роману испољена је кроз преображај субјекта, а као резултат односа према губицима на више нивоа. Бол услед физичког нестанка особе нужно се интезивира психолошким набојем мисли и извесно доводи до психичког растројства, јер губитак са знаком непостојања некога/нечега претпоставља психолошко задржавање изгубљеног кроз мисао, сећање и асоцијацију путем предмета.

Гавре Ђаковић одлучује да напусти студентски живот гунгуле у граду и да се врати завичају, надајући се да ће породична кућа, а затим отац, брат и мајка оживети учмалост градског живота, јер непосредно пред одлазак: „Он је сазнао у једном трену да не може више да живи међу њима; узрујавала су га та непроменљива лица која редовно виђа [...] као и његова стара ђачка соба, пуна нереда, која се већ уживила у њега"7. Долази до првог наговештаја смртности, јер уколико се предмет/соба уживи у човека нужно је убијање животности и уношење мртвила кроз беживотни простор/ собу. Уколико човек, као биће, уноси живот у одређени простор, онда код Милићевића долази до замене места, те соба, са ознаком неживог постаје надређена у односу на Гавру, као живу јединку. Међутим, повратак на село претпоставља отварање новог нивоа смртности, или пак, затварање наде понесене из града. Отуда, сам чин путовања ка родном селу, учитава смрт: кроз призоре, погледе, осећаје. Воз „се поново кретао у таму, у непознату даљину, пуну мрака, бунећи својом тупом ломљавином мртвачку тишину заспалих поља; наличио на немирну и несрећну животињу која јури преко

4 В. Јовановић, Идентитет и смрт субјекта, „Синтезис: часопис за хуманистичке науке и друштвену стварност” 2009, бр. 1, с. 65.

5 Ibidem, c. 67.

6 В. Милићевић, Бесnуће..., с. 11.

7 Ibidem, c. 10. 
мртвих предјела, кроз једну вазда исту ноћ, као да тражи пута кога нема”, а Гаври „очни капци бијаху тешки и запаљени, уста му бијаху горка, и оловна малаксалост умртвљаваше му цело тело" 8 . Две паралелне слике, предметна и људска, сустичу се као подједнаки репрезенти смрти која ће достићи свој врхунац на крају путовања, а које је почетак осипања живота у субјекту. Пут којега нема оцртава мапу животног пута Ђаковића у друштвеним околностима 19. века, јер најпре ће путем немогућег циља кренути Гавре, а затим брат и отац.

Повратак на село, као на место раног сазревања Гавре Ђаковића пут је тражења узрока Гаврине учмалости у граду. Јовановић, позивајући се на Мида, наводи да се још од првих дечијих игара и комуникације са одраслима формира систем којега ће се субјекат у зрелом периоду придржавати ${ }^{9}$. Стога је Гаврино враћање на период породичног живота са знаком различитих смрти нужан узрок Гаврине емоционалне и сексуалне смртности, приказане у одбијању женског принципа посредством двеју жена у роману, Јеке и Ирене Панек. Није могућно Гаврино социјално и емотивно узглобљење, нити повезивање посредством љубави, јер ако су љубав и сексуалност предчинови рађања и стварања новог живота, Гавре је онемогућен смрћу уписаном још у детињству. Стога се смрт у биолошки живом човеку посматра као последица односа према некоме/нечему, јер како сматра Златановић, позивајући се на Гергена: „у питању је, дакле, одбацивање супстанцијализоване концепције самства [.. .] јер самствено није обједињена психолошка целина, него је сложај неинтегирасних представа и доживљаја и оно постоји кроз своје односе са другим самствима (особама) и реалношћу која је сама фрагментисана"10. Управо је Гавре Ђаковић одраз хетерогеног субјекта чији су разнородни психолошки супституенти последица односа и сећања према људима и предметима, а који заправо и творе животни пут субјекта. Материјално и духовно, кућа и дом те другост као знак припадања, представљају принципе стварања субјекта као психолошки (не)стабилног. Емотивна истанца у знаку негативности, изазвана пропадањем и смрћу, чини да Гавре постане расцепљена слика Другог са којим јесте или је била у (не)посредном односу.

Повратак кући, као почетној тачки нужан је, јер како сматра Јевремовић: „Ако је, између осталог, прича о смртности, прича о граници, а она то несумњиво јесте тада доиста важи она древна (пресократовска) интуиција, која, савим недвосмислено каже да је наша граница (тј. граница нашег сопственог бића) оно где почињемо, а не где престајемо"11. Породична кућа

8 Ibidem, c. $15-16$.

9 В. Јовановић, Идентитет..., с. 67-69.

${ }^{10}$ Lj. Zlatanović, Postmodernizam i „,smrt subjekta” - ka dekonstrukciji samstva, „Godišnjak za psihologiju" 5, 2008, br. 6/7, c. 87.

11 П. Јевремовић, Савремена психоанализа и трагичко искуство субјекта самосвести, „Источник: часопис за веру и културу” 2006, бр. 59/60, с. 127. 
постаје траг сећања на породични дом, одуством породице остаје само архитектонска грађевина, што је окаменила предметност, но не и живот. Ствари што су Гавру дочекале непомично сведоче о непостојању оних који би се стварима служили. Пропадање у непомичности интезивира не укидање живота, јер живот је већ поништен, већ творење смрти као најсвежије актуелности. Стога се људска смрт директно транспонује у предметну неупотребљивост, а психолошко уништење живог, Гавре, увећано је болом који прозиводи смрт/предмет:

Зидови су били тако хладни, тако нетопли, тако дуго незагријевани ничијим дахом; покућство је било непомично као урасло у испуцани црни, издерани под, немицано тако дуго времена и запрашено; [...] завјесе на прозорима остарјеле, неразмицане ничијом руком ${ }^{12}$.

Гаврина дескрпиција собе једина је могућна, јер двоструки не-живот куће презентује смрт и грађевине и људи. Уколико комуникацијски чин претпоставља говорника и саговорника, онда се комуникација укида, јер Гавре нема саговорника. Условни саговорник јесте сопство кроз две димензије: садашњост и прошлост. Отуда и урањање у прошлост, као време живота, остварено је изнова посредством смрти/предмета/слике:

Неки дан [...] оборио је случајно једну малу слику, он се преко воље и љутито сагнуо - зар га и ти људи, објешени на зидове и затворени у оквире, почеше да сметају? - и загледао се у њу. [...] и погледа поново. То је био његов брат Милан [...] то је био он на кога није тако дуго мислио, кога није препознао; како смрт одрађа ${ }^{13}$.

Пробијање оквира извршено је двоструким чином излажења мртвих из таме неизречености и оживљавање у свести Гавре Ђаковића. Није могућно да се узглоби смрт, да се мртви брат сахрањивањем укине, сећање, привид и одјеци некдашњег живота почињу да потискају живог Гавру Ђаковића, постајући свеприсутност, јер на једној је страни Гавре/живот, а на другој победнички пар смрти: мртвих предмета и мртвих укућана. Билијарска лопта с почетка преображава се у слику са зида чији пад одјекује мртвилом собе и Гавриних мисли. Уколико се појам игре посматра са становишта Ђорђевића ${ }^{14}$ који наводећи Гроса посматра игру као извесну вежбу за несреће у животу, онда је у Бесnyћy дословно успостављена игра на нивоу однос живот/појединачно/Гавре и смрт/опште/укућани/предмети. У тако креираној игри Гавром се поиграва, јер смрт увек надвладава живот: „Док је живот будан смрт спава. Када се смрт пробуди, тј, када она буде ослобођена живот ишчезава"15. Но игра какву даје Милићевић не претпоставља коначност пораза кроз Гаврину смрт, већ континуиране губитке који најзад воде до испразног живота, али не и до укидања истог. Гавре није

\footnotetext{
12 В. Милићевић, Беспуће..., с. 20.

13 Ibidem, c. 21-22.

14 Т. Р. Ђорђевић, Српске народне игре, књ. 1, Београд 1907, с. 4.

15 П. Јевремовић, Савремена психоанализа.., с. 7.
} 
вољни учесник у игри, већ постаје средство, експеримент над људским животом који гледа у смрт. Стога и сећања навиру као поновни докази људске немогућности. Контакт са Милановом сликом пробиће границе садашњости и вратити Гавру на тренутке смрти другости које су и мртве - живе. Временско измештање у време сазнања о Милановом самоубиству изнови уводи мотив воза као пута ка смрти. Милићевић доследно спроводи просторно, временско и психолошко понављање, чиме унапред укида могућност будућег, као новог почетка и живота.

Смрћу појединца завршава се његов живот, но за оног који остаје почиње нови живот кроз психолошко-емоционални однос са умрлим. Психологија живог постаје нераскидиво везана за тренутак смрти другог. Једном је вест о смрти, други пут сећање о вести, у оба случаја онај који је жив, Гавре Ђаковић, поима смрт као подједнако актуелну и болну, јер смрт брата имплицираће смрт и мајке, најпре психички, а затим и дословно. Психолошка смрт постаје најболнија, јер не допушта прекид са мртвом особом, већ интезивира бол трајањем мртвих у живом Гаври. Условно заборављена смрт пројицира се у Гавриној свести као жива, свеприсутна, и уколико мртви Милан пробија оквир рама слике, онда Гавре долази на место уоквирености. По рубовима живота је смрт, у центру смрти живи је Гавре. Стога је и свако учитавање стварности једнако учитавању смрти:

Колико је било несреће и студени, - оне студени која не долази споља, већ из душе, и која је још страшнија и леденија - у тој хладној несређеној соби, у тој жени, згуреној у куту, која ћути, која се не миче, с погледом који више ништа не схвата, за коју је с њезиним сином умро читав живот изван ње која је приглила врелу и и крваву успомену у своје груди, створила у себи слику свог сина [...] преживљавајући стотину пута његову смрт, умирући заједно с њим тешком и мученом смрћу ${ }^{16}$.

Мотив слике креће се у концентричном кругу, од мајке која креира слику живога сина до слике на зиду, јер смрћу мајке више не постоји живот који чува успомену на Милана. Сада једна смрт изазива другу и обе постају подједнако актуелне. Смрћу мајке, успомена на заборављеног Милана намеће се Гаври, и премда је не прихвата, пад слике са зида која објављује глас у немој кући, указује Гаври да тај простор није више дом, већ стециште смрти. Уколико је уживљавање студентске собе представљало наговештај смрти, утолико је простор породичне куће експлицитно објављивање нихилизма. Мајчина смрт пре смрти обилује хладноћом, јер уколико је смрт хладна и непомична, онда је онај који је доживљава као сопствену (мајка) подједнако психички мртва. Гавре сада постаје стециште и мајчине смрти, која је и постојала само као сведочанство о смрти: „Он климну лагано главом и окрену се у страну тихо и заплака, што није радио до тада, осјетивши у том тренутку, што је смрт"17. Осетити смрт за Гавру је

\footnotetext{
16 В. Милићевић, Беспуће..., с. 28.

${ }^{17}$ Ibidem, c. 29.
} 
осећање свежине бола који показује колико су уистину живи они који беху наизглед заборављени. Наместо успомене и сећања долази до транспоновања прошлости што чини да помисао на негдашње смрти креира нову смрт субјекта који је жив. Покрет који обара предмет конгруира психолошки са током мисли који оживљава прошлост.

Сећања на смрти у Бесnућу нижу се градацијски. Ново сећање јесте нова смрт. У низу умирања, смрт оца претпоставља свеукупност смрти: идеала породице, друштвеног живота и животног хтења. Уколико се пође од претпоставке Јурице ${ }^{18}$, који сматра да је сваки покушај прелажења границе, једнак преласку руба живота, онда је смрт очева евидентан доказ преласка у животну немогућност - смрт. Потирањем живота свакодневнице уз сан о посебном друштвеном положају, најзад се и живот и смрт унижавају. Живот кроз слику умирања, а смрт кроз сам чин сахране, која је представљена као свакодневни, ужурбани посао. Сахрањивање оца изнова нас враћа почетку романа и кафанској гунгули у којој се људи мимоилазе. Сада су се мимоишле животне (не)могућности, а ако је живот шанса, а смрт одвећ искоришћена шанса, поставља се питање шта су Ђаковићи од живота искористили? Хотећи прелазак с оне стране животне шансе неминовно су прешли у простор смрти. Међутим, за Гавру, који иза смрти остаје, креира се нови живот, прочишћен од животних принципа, те је Гаврино битисање пројекција смрти у егзистенцијалном трајању. Наиме, уколико се присетимо Бодријара, смрт је управо главно оружје против смрти: „Требало би смрћу играти против смрти - радикална таутологија; створити апослутно оружје од логике самог система"19. Отуда Гаврино порицање женског принципа, укорењености и најзад, порицање цркве и Бога, јер уколико је систем смрт, а појединац живот, нужно је укинути појединца као животно плодотворног. Уколико Гавре не завршава свој живот самоубиством, онда је нужно одрицање од живота како би остао у животу. Најзад, постојањем система којему већ по рођењу припада Гавре Ђаковић, а који је уписао смрт на Гавриној животној путањи, субјекат нема могућност избора. Једини условни избор јесте биолошка смрт и/или психолошка смрт. Но биолошка смрт није могућна, јер је живи Гавре неопходан Милићевићевом дискурсу како би посведочио постојање смрти: људске, трансцеденталне, психолошке, предметне. Сваки ниво разграђује се у свом појединачном микросистему, но сви упућују на централни елемент који не само што психолошки посредује, већ и освешћује себе у новој димензији, која је најранија димензија развоја - време проведено у кући које исписује причу осам година касније. Ретроспектива јунака јесте Милићевићева поновна игра са јунаком, који да би причао о смрти, мора затворити путању са које је пошао. Милићевићев јунак постаје свестан немогућности ослобађања од смрти, а управо је свест

${ }^{18}$ N. Jurica, Melankolija ili predvorje smrti, „Delo” 1985, br. 8/9, c. 96-105.

19 Ž. Bodrijar, Simbolička razmena i smrt, prev. M. Marković, Gornji Milanovac 1991, c. 391. 
о смрти могућност спознаје себе и могућног живота јер: „Да би се субјект себи показао [...] потребно је било, и нужно, да себи буде објекат [...] стога се он, да би се видео, морао и поделити" ${ }^{\text {"20 }}$. Гавре Ђаковић бива проживљен изнова од стране сопства временски, просторно и психолошки, како би се изнова пројицирао у ново/најстарије $j a$, а које, након свих смрти, више није са остатком заборављених смрти, већ целина свеукупних смрти. Такав субјекат потире и религиозни принцип, као могуће избављење.

Гавре Ђаковић, као једини живи Ђаковић постаје укрштај смрти сопствених идеала: промашеног студентског живота, немогућег живота у завичају, сексуалног и емотивног незадовољства те смрти што поништавају Гавру као сина, брата, студента и најзад, као емоционално живог човека. Долази до поништавања патријахалног, хуманистичког и емоционалног принципа што претпоставља одрицање од живота какав се у хришћанском смисли нуди. Бесnyћe сажима друштвено, породично и лично пропадање, те је фигура смрти посматрана кроз биолошко, транцедентално и психолошко умирање.

\section{Библиографија}

Bodrijar Ž., Simbolička razmena i smrt, prev. M. Marković, Gornji Milanovac 1991.

Đorđević R. T., Srpske narodne igre, knj. 1, Beograd 1907.

Jevremović P., Savremena psihoanaliza i tragičko iskustvo subjekta samosvesti, „Istočnik: časopis za veru i kulturu" 2006, br. 59/60.

Jovanović V., Identitet i smrt subjekta, „Sintezis: časopis za humanističke nauke i društvenu stvarnost" 2009, br. 1.

Jurica N., Melankolija ili predvorje smrti, „Delo” 1985, br. 8/9.

Kordić R., Subjekat teorijske psihoanalize, Novi Sad 1994.

Milić N., ABC Dekonstrukcije, Beograd 1998.

Milićević V., Bespuće, Beograd 1982.

Zlatanović Lj., Postmodernizam i ,smrt subjekta” - ka dekonstrukciji samstva, „Godišnjak za psihologiju" 5, 2008, br. 6/7.

\section{Psychological aspects of the figure of death in Veljko Milicevic's Bespuce}

\section{Summary}

The article is devoted to the psychological aspects of death in Veljko Milicevic's Bespuce, a novel depicting the psychological state of the protagonist caused by numerous losses. By analyzing different attitudes towards death represented by Gavre Djakovic, the author of this article tries to show how the figure of death corresponds with the loss of Gavre's loved ones and his ideals. The purpose of this article is to analyze the experiences of the protagonist who is facing a series

${ }^{20}$ R. Kordić, Subjekat teorijske psihoanalize, Novi Sad 1994, s. 16. 
of losses: the death of his father, mother, and brother, as well as dissatisfaction with his ideological beliefs. These events affect the emotional state of Gavre: they do not lead to his death, but fill his life with a negative attitude to everything that surrounds him, devastating his life. Therefore, in the novel, the psychological aspect of death is represented by the attitude of the protagonist towards life and his reactions to loss.

Keywords: death, deconstruction of the subject, identity of the subject, Bespuce, helplessness

\section{Психологические аспекты феномена смерти в романе Беспуче Велька Миличевича}

\section{Резюме}

В данной работе рассматриваются психологические аспекты проблемы, смерти в романе Велька Миличевича Беспуче. В этом романе представлено психологическое состояние главного героя, вызванное многочисленными утратами. Мы попытались показать, как образ смерти соотносится со смертью близких людей и утратой идеалов. Цель нашей работы проанализировать переживания главного героя, Гаврилы Джаковича, переживающего череду потрясений: смерть отца, матери и брата, разочарование в идеологических убеждениях. Эти события влияют на эмоциональное состояние Гаврила: они не приводят к смерти героя, но наполняют его жизнь негативным отношением ко всему, что его окружает, опустошают его жизнь. Психологический аспект проблемы смерти раскрывается через отношения главного героя к жизни и его реакцию на утраты.

Ключевые слова: смерть, деконструкция личности, Беспуче, опустошение 